\title{
GAMBARAN PENGETAHUAN IBU TENTANG PEMBERIAN GIZI PADA BALITA WILAYAH KERJA UPTD PUSKESMAS SOGAE'ADU KABUPATEN NIAS TAHUN 2018
}

\author{
1.Mukhtar Effendi Harahap, ${ }^{2 \cdot}$ Martinus Lombu \\ Dosen Prodi S1Keperawatan, STIKes Imelda, Jalan Bilal Nomor 52 Medan; \\ Alumni STIKes Imelda \\ Email: 1. effendimuktar2@gmail.com,$^{2}$ martinuslombu@gmail.com
}

\begin{abstract}
ABSTRAK
Secara etimiologi kata "Gizi” berasal dari bahasa Arab "Ghidza”, yang berarti "Makanan” Menurut dialek Mesir, "Ghidza" dibaca dengan "Ghizi”. Sehingga gizi dikatakan adalah suatu proses penggunaan makanan yang dikonsumsi secara normal oleh suatu organisme melalui proses digestif, absorpsi, transportasi, penyimpanan, metabolisme dan pengeluaran zat-zat yang tidak digunakan untuk mempertahankan kehidupan, pertumbuhan dan fungsi normal dari organ-organ serta menghasilkan energi (Ramadhan, 2012). Jenis Penelitian ini adalah deskriptif.Metode mengambilan sampel probability sampling dengan total sampling dimana jumlah sampel sebanyak 68 ibu yang membawa balitanya dalam pemenuhan nutrisi ke Puskesmas Sogae'adu Kabupaten Nias Tahun 2018.Pengumpulan data dilakukan menggunakan kuesioner yang terdiri dari 12 pertanyaan, Tehnik pengukuran pertanyaan menggunakan skala Guttman, dalam bentuk kuesioner tertutup.Kemudian hasil kuesioner diformulasikan kedalam interval jawaban variabel menggunakan rumus Sturgers untuk menentukan kriteria jawaban responden dan mengetahui skor dan persentase jawaban.Dari hasil penelitian ditemukan bahwa mayoritas tingkat pengetahuan responden cukup berjumlah 34 orang (50\%), sedangkan berpengetahuan baik hanya 20 orang (29,4\%) dan yang berpengetahuan buruk berjumlah 14 orang (20, $6 \%$ ). Untuk itu diharapkan Dokter, Perawat, Bidan, Ahli gizi, serta dibantu oleh tenaga kesehatan yang lain dapat memberikan penanganan yang cepat dan tepat pada kasus gizi buruk baik di tingkat puskesmas maupun di rumah sakit, untuk membantu pemulihan kasus gizi buruk pada anak balita. Bidan sebagai tenaga kesehatan harus selalu memberikan konseling dan penyuluhan tentang pentingnya pemberian gizi yang tepat sesuai dengan usia dan perkembangannya.
\end{abstract}

Kata kunci : Pengetahuan, Ibu, Balita, Pemberian Gizi

\section{PENDAHULUAN}

Tingginya angka kematian bayi dan anak merupakan ciri yang umum dijumpai di negara-negara yang sedang berkembang termasuk Indonesia. Angka kematian bayi dan anak tersebut bisa saja disebabkan salah satu faktornya yaitu tentang pemberian asupan gizi yang kurang memadai. Menurut Sue Kimm, (2010) dalam bukunya, istilah kurang Energi-Protein sekarang dipandang sebagai suatu permasalahan ekologis dimana tidak saja disebabkan oleh ketidakcukupan ketersediaan pangan atau zat-zat gizi tertentu tetapi juga dipengaruhi oleh kemiskinan, sanitasi lingkungan yang kurang baik dan ketidaktahuan terhadap gizi (Dwijayanti, Linda. 2015).

Masa balita adalah periode perkembanga $\mathrm{n}$ fisik dan mental yang pesat.Pada masa ini otak balita telah siap menghadapi berbagai stimulasi seperti belajar berjalan dan berbicara lancar.Kondisi otak dan fisik anak dikemudian hari tergantung dari jenis dan jumlah makanan yang di berikan kepadanya, sejak masih kandungan sampai masa kanakkanak. Balita memiliki kebutuhan gizi yang berbeda dari orang dewasa.Mereka butuh lebih banyak lemak dan lebih sedikit serat.Cermati perbedaan ini saat ibu merencanakan menu makan balita.Untuk itu pengetahuan ibu tentang perawatan bayi dan anak-anak prasekolah boleh dikatakan penting sekali untuk menciptakan generasi masa datang yang lebih baik dan peran ibu menjadi faktor penentunya (Proverawati dkk, 2010).

Berdasarkan laporan organisasi kesehata n dunia atau WHO menunjukkan kesehatan balita Indonesia terendah di ASEAN dengan peringkat ke 78 dari 170 negara. Pem erintah Indonesia mengklaim 900 ribu 
Balita Indonesia mengalami gizi buruk.Angk a tersebut menempatkan Indonesia di peringkat kelima di Dunia sebagai Negara dengan bayi kekurangan gizi terbanyak (Ashaluddin, 2011).

Direktur Gizi Masyarakat Kementerian Kesehatan "Minarto" mengatakan, angka prevalensi kekurangan gizi di Indonesia sejajar dengan Filipina dan Vietnam. "Gizi buruk itu angkanya menurut Riskesdas (Riset Kesehatan Dasar) 2014berkisar $4 \%$ dari 22 juta balita atau sekitar 900 ribu balita dan itu tersebar di berbagai Desa, Kabupaten, dan Kecamatan yang kita data melalui Pos Pelayanan Terpadu (Posyandu) (Dwijayanti, Linda. 2015). Prevalensi balita menurut status gizi $(\mathrm{BB} / \mathrm{U})$ secara Nasional di Indonesia yaitu gizi buruk sebesar 5,4\% dan gizi kurang $13 \%$. Sedangkan merujuk laporan Riskesdas 2012 di Sumatera Utara, menunjukkan bahwa prevalensi balita menurut status gizi $(\mathrm{BB} / \mathrm{U})$ di Propinsi Sumatera Utara yaitu gizi buruk 8,4 dan gizi kurang $14,3 \%$ lebih tinggi dibandingkan angka nasional (Profil Kesehatan Propinsi Sumatra Utara,2014).

Pada bulan april 2015 lalu, di Kota Medan dengan melakukan operasi timbang selama seminggu ditemukan 1.000 lebihkasus gizi buruk. Setelah di update, jumlah kasus gizi buruk menurun menjadi 500 kasus diseluruh kecamatan di Kota Medan. Masih dari sumber yang sama, dari hasil pendataan pada bulan Januari 2016, Dinas Kesehatan Kota (DKK) Medan

mengeluarkan data gizi buruk di Kota Medan ditemukan sebanyak 126 kasus bila dilihat dari

data yang dikeluarkan DKK Medan ada kece nderungan menurun, masalah gizi buruk tetap menjadi ancaman, selama persoalan ekonomi dan pengetahuan masyarakat masalah gizi re ndah (Santosa, Sugeng. 2016).

Menurut Bupati Nias Sokhiatulo Laoli ada beberapa permasalahan kesehatan yang dihadapi Kabupaten Nias. Salah satunya yaitu gizi kurang dan gizi buruk pada Balita yaitu $1.04 \%$. Bupati Nias menyebutkan bahwa permasalahan kesehatan di Nias dikarenakan beberapa sebab.Kepulauan Nias berada di wilayah perbatasan, terpencil, rawan bencana alam, serta masih rendahnya kemampuan ekonomi masyarakat. Di sisi lain ketersediaan sumber daya, baik tenaga, dana dan peralatan masih terbatas, terang Bupati Nias. Menanggapi permasalahan kesehatan ini, Menkes menyatakan bahwa Kepulauan Nias memang salah satu wilayah kepulaian dengan kondisi geografi yang penuh tantangan. Kondisi ini sangat berpengaruh pada akses masyarakat akan pelayanan kesehatan yang $\mathrm{k}$ omprehensif dan bermutu. Oleh karena itu, ja jaran Pemda Provinsi dan Kabupaten/ Kota se tempat agar memberikan perhatian sungguhsungguh pada pelayanan kesehatan di wilayah yang sulit terjangkau serta mendukun g keberhasilan upaya peningkatan derajat kesehatan masyarakat di wilayah kerjanya. Tidak hanya keberadaan infra struktur yang menunjang pelayanan publik seperti ketersediaan fasilitas pelayanan kesehatan yang dibutuhkan,melainkan juga tenaga kesehatan (DEPKES RI, 2014).

Berdasarkan survey awal peneliti di wilayah kerja UPTD Puskesmas Sogae'adu pada bulan Januari - Juni Tahun 2018, diketahui kurangnya pengetahuan Orang Tua tentang pentingnya Imunisasi dan pemenuhan Gizi pada Balita ditandai dengan Imunisasi pada Balita yang lengkap sebanyak 586 Balita (67\%), Tidak lengkap sebanyak 276 (32\%), Tidak Imunisasi sama sekali sebanyak 12 Balita (1\%), Berat Badan Balita yang golongan kurang sebanyak 59 Balita (7\%), Berat Badan golongan buruk sebanyak 14 Balita (2\%), Gizi Balita yang golongan kurang sebanyak 44 Balita (5\%) dan Gizi Balita yang golongan buruk sebanyak 6 Balita $(0,70 \%)$.

\section{Rumusan Masalah}

Berdasarkan latar belakang tersebut maka penulis tertarik untuk melakukan penelitian tentang "Gambaran Pengetahuan Ibu Tentang Pemberian Gizi Pada Balita di wilayah kerja UPTD Puskesmas Sogae'adu Kabupaten Nias Tahun 2018”.

\section{Tujuan Penelitian Tujuan Umum}

Penelitian ini bertujuan untuk mengetah uiGambaran Pengetahuan Ibu Tentang Pemberian Gizi Pada Balita di wilayah kerja UPTD Puskesmas Sogae'adu Kabupate n Nias Tahun 2018. 


\section{Tujuan Khusus}

1. Bagaimanakah pengetahuan orangtua tentang sakit dan penyakit berhubungan dengan pemberian gizi pada balita?

2. Bagaimana pengetahuan orangtua tentang pemeliharaan kesehatan dan cara hidup sehat berhubungan dengan pemberian gizi pada balita?

3. Bagaimana pengetahuan orangtua tentang kesehatan lingkungan berhubungan dengan pemberian gizi pada balita?

\section{Manfaat Penelitian}

1. Untuk menambah pengetahuan dan mengembangkan sikap serta perilaku seorang ibu dalam keluarga khususnya dalam rangka pemenuhan asupan nutrisi pada balita.

2. Sebagai bahan masukan para petugas kesehatan dalam hal perencanaan pemberian pengetahuan dan mengembangkan sikap serta perilaku seorang ibu dan pencegahankurangnya asupan nutrisi pada balita.

3. Penelitian ini digunakan sebagai media pembelajaran untuk mengaplikasikan ilmu pengetahuan tentang pengetahuan masyarakat khususnya ibu dalam rangka pemenuhan asupan nutrisi pada balita.

4. Memberikan manfaat bagi peneliti selanjutnya agar dapat merencanakan penelitian lanjutan dalam konteks asuhan keperawatan secara menyeluruh.Sehingga dapat diharapkan memberikan kontribusinya dalam pelayanan kesehatan ibu dan balita.

\section{METODE}

Penelitian dalam studi ini menggunakan metode penelitian Deskriptif dengan mengg unakan pendekatan CrossSectional yaitu mel akukan penelitian dalam sekali waktu secara bersamaan. Penelitian ini dilaksanakan pada bulan Juni - Juli tahun 2018.Dilakukan di wilayah kerja UPTD Puskesmas Sogae'adu Kabupaten Nias Tahun 2018. Jumlah populasi dalam penelitian ini berjumlah 272 ibu yang berada di wilayah kerja UPTD Puskesmas Sogae'adu Kabupaten Nias Tahun 2018. Metode Sampling yang digunakan adalah Insidental Sampling, berdasarkan tehnik sampling diatas, jumlah sampel yang terkumpul dalam penelitian ini berjumlah 68 ibu yang memiliki balita di wilayah kerja UPTD Puskesmas Sogae'adu Kabupate $\mathrm{n}$ Nias. Tehnik pengukuran pada setiap variabel adalah dengan mengajukan pertanya an menggunakan skala Guttman, dalam bentuk kuesioner tertutup kepada responden untuk mengetahui pengetahuan ibu dengan mengajukan 12 butir pertanyan. Interval jawaban variabel menggunakan rumus Sturgers.

\section{HASIL}

Data Umum

Tabel 1. Distribusi Frekuensi Responden Berdasarkan Umur Ibu

\begin{tabular}{llll}
\hline No & Umur (Tahun) & $\mathbf{f}$ & $\begin{array}{l}\text { Persentase } \\
(\%)\end{array}$ \\
\hline 1 & $12-20$ & 21 & 30,88 \\
\hline 2 & $21-40$ & 47 & 69,22 \\
\hline 3 & $41-50$ & 0 & 0 \\
\hline \multicolumn{2}{l}{ Total } & $\mathbf{6 8}$ & $\mathbf{1 0 0 \%}$ \\
\hline
\end{tabular}

Dari tabeldiatas dapat dilihat bahwa mayoritas usia ibu yang memilki balita dengan kategori umur 21 - 40 Tahun sebanyak 47 orang $(69,22 \%)$ sedangkan ibu yang memilki balita dengan kategori umur 12 - 25 Tahun sebanyak 21 orang $(30,88 \%)$, dan ibu yang memiliki balita dengan kategori umur 41 - 50 Tahun tidak ditemui.

Tabel 2. Distribusi Frekuensi Responden Berdasarkan Pendidikan Ibu

\begin{tabular}{llll}
\hline No & Pendidikan & $\mathbf{f}$ & $\begin{array}{l}\text { Persentase } \\
(\boldsymbol{\%})\end{array}$ \\
\hline 1 & SD & 27 & 39,7 \\
\hline 2 & SLTP & 28 & 41,1 \\
\hline 3 & SLTA & 7 & 10,1 \\
\hline 4 & D3/S1/Sederajat & 7 & 10,1 \\
\hline Total & & $\mathbf{6 8}$ & $\mathbf{1 0 0 \%}$ \\
\hline
\end{tabular}

Dari table diatas dapat dilihat mayoritas pendidikan ibu yang memilki balita dengan $\mathrm{k}$ ategori berpendidikan SLTP berjumlah 28 orang $(41,1 \%)$, sedangkan ibu yang memilki balita dengan kategori pendidikan SD berjumlah 27 orang $(39,7 \%)$, dan untuk ibu yang memiliki balita dengan kategori SLTA dan D3/S1/Sederajat masing-masing berjumlah 7 orang $(10,1 \%)$. 
Tabel 3. Distribusi Frekuensi Responden Berdasarkan Sumber Informasi

\begin{tabular}{llll}
\hline No & $\begin{array}{l}\text { Sumber } \\
\text { informasi }\end{array}$ & Frekuensi & $\begin{array}{l}\text { Persenta } \\
\text { se (\%) }\end{array}$ \\
\hline 1 & $\begin{array}{l}\text { Tenaga } \\
\text { kesehatan }\end{array}$ & 22 & 32,4 \\
\hline 2 & Kerabat/keluarga & 18 & 26,4 \\
\hline 3 & Media cetak & 12 & 17,6 \\
\hline 4 & Media elektronik & 16 & 23,6 \\
\hline Total & $\mathbf{6 8}$ & $\mathbf{1 0 0 \%}$ \\
\hline
\end{tabular}

Dari tabel diatas dapat dilihat 68 ibu yang memiliki balita, mayoritas memperoleh sumber informasi melalui Tenaga kesehatan berjumlah 22 orang $(32,4 \%)$. Kerabat/Keluar ga berjumlah 18 orang $(26,4 \%)$, Media cetak berjumlah 12 orang $(17,6 \%)$ dan ibu yang memilki balita memperoleh informasi melalui Media elektronik berjumlah 16 orang $(23,6 \%)$.

Tabel 4. Distribusi Frekuensi Responden Berdasarkan Pekerjaan Ibu

\begin{tabular}{llll}
\hline No & Pekerjaan & f & Persentase (\%) \\
\hline 1 & IRT & 29 & 42,6 \\
\hline 2 & Bertani & 21 & 30,9 \\
\hline 3 & Wiraswasta & 15 & 22,1 \\
\hline 4 & PNS & 3 & 4.4 \\
\hline \multicolumn{2}{l}{ Total } & $\mathbf{6 8}$ & $\mathbf{1 0 0 \%}$
\end{tabular}

Dari tabel diatas dapat dilihat dari $68 \mathrm{ibu}$ yang memilki balita, mayoritas pekerjaan ibu hanya sebagai IRT berjumlah 29 orang $(42,6 \%)$, sedangkan ibu yang memiliki balita dengan pekerjaan Bertani berjumlah 21 orang $(30,9 \%)$, Wiraswasta berjumlah 15 orang $(22,1 \%)$ dan ibu yang memilki balita dengan pekerjaan sebagai PNS berjumlah 3 orang $(4,4 \%)$

\section{Data Khusus}

Tabel 5. Distribusi frekuensi pengetahuan Tentang Gambaran Pengetahuan Ibu Dalam Pemberian Gizi Pada Balita di wilayah kerja UPTD Puskesmas Sogae'adu Kabupaten Nias Tahun 2018

\begin{tabular}{llll}
\hline No & Pengetahuan & f & Persentase(\%) \\
\hline 1 & Baik & 20 & 29,4 \\
\hline 2 & Cukup & 34 & 50 \\
\hline 3 & Buruk & 14 & 20.6 \\
\hline Total & & $\mathbf{6 8}$ & $\mathbf{1 0 0 \%}$ \\
\hline
\end{tabular}

Berdasarkan tabel diatas dapat dilihat mayoritas tingkat pengetahuan ibu yang memilki balita dengan kategori cukup berjumlah 34 orang(50\%), sedangkan Ibu yang memilki balita dengan kategori berpengetahuan baik hanya 20 orang $(29,4$ $\%$ ) dan ibu yang memilki balita dengan kategori berpengetahuan buruk berjumlah 14 orang $(20,6 \%)$.

\section{PEMBAHASAN}

Pengetahuan ibu dalam pemberian gizi pada balita di wilayah kerja UPTDPuskesmas Sogae'adu Kabupaten Nias. Menunjukkan bahwa dari 68Ibu yang memilki balita yang menjadi responden bahwa mayoritas tingkat pengetahuan Ibu dengan kategoricukup berjumlah 34 orang $(50 \%)$. Peneliti berasums i bahwa hal ini dipengaruhi oleh usia ibu yang memilki balita sebahagian masih ditemui berusia 12 - 25 Tahun sebanyak 21 orang $(30,88 \%)$, sesuai dengan teori Notoadmodjo (2010). Usia mempengaruhi terhadap daya tangkap daya dan pola pikir seseorang semakin bertambah usia akan semakin berkembang pula daya tangkap dan pola pikirnya, sehingga pengetahuan yang di perolehnya semakin membaik. Faktor lain ditambahkan mayoritas responden memperol eh sumber informasi kesehatan diperoleh langsung melalui Tenaga kesehatanhanya berjumlah 22 orang $(32,4 \%)$ saja ditambah mayoritas pekerjaan ibuhanya sebagai IRT berjumlah 29 orang $(42,6 \%)$, Bertani berjumlah 21 orang $(30,9 \%)$, Wiraswasta berjumlah 15 orang $(22,1 \%)$ dan PNS berjum lah 3 orang $(4,4 \%)$. Pengetahuan selain bersumber dari pendidikan dan pengalaman juga berasal dari sumber informasi yang didapatnya.

Seseorang masyarakat didalam proses pendidikan juga dapat memperolehpengetahu an dari berbagai macam alat bantu / media (BKKBN, 2005). Sesuai dengan teori Notoadmojo (2010) adapun faktor - faktor yang mempengaruhi pengetahuan (usia, sosial dan budaya, media informasi, pendidikan, pengalaman dan lingkungan) disini peneliti membandingkan hasil penelitian dengan teori yang ada.

Peneliti dapat menyimpulkan bahwa pengetahuan ibu yang memilki balita di wilayah kerja UPTD Puskesmas Sogae'adu Kabupaten Nias ini terkategori cukup 
dikaitkan dengan media informasi yang masih kurang ditandai dengan masih minimnya masyarakat menggunakan sarana pelayanan kesehatan yang berpusat di Puskesmas Sogae'adu Kabupaten Nias. Namun, keterbatasan fasilitas dan tingkat pendidikan menjadi salah satu faktor penghambat seorang ibu yang memilki balita untuk mendapatkan pengetahuan yang baik dan menentukan sikap yang baik dalam pemenuhan gizi pada balita. Hal ini terlihat dari hasil mayoritas responden ditemukan berpendidikan SD berjumlah 27 orang $(39,7$ $\%)$, SLTP berjumlah 28 orang (41,1 $\%)$,SLTA dan D3/S1/Sederajat masingmasing berjumlah 7 orang $(10,1 \%)$.Disini sangatlah penting peranan tenaga kesehatan untuk meningkatkan pengetahuan ibu hamil dengan memberikan pendidikan tentang pemenuhan gizi pada balita (BKKN, 2014).

\section{KESIMPULAN}

Peneliti dapat menyimpulkan bahwa pengetahuan ibu di wilayah kerja UPTD Puskesmas Sogae'adu Kabupaten Nias ini terkategori cukup dikaitkan dengan media informasi yang masih kurang ditandai dengan minimnya masyarakat menggunakan sarana pelayanan kesehatan yang berpusat di wilayah kerja UPTD Puskesmas Sogae'adu Kabupaten Nias. Namun, keterbatasan fasilitas dan tingkat pendidikan menjadi salah satu faktor penghambat seorang ibu untuk mendapatkan pengetahuan yang baik dan menentukan sikap yang baik dalam pemberian gizi pada balita.

\section{SARAN}

1. Bagi Institusi Pendidikan Keperawatan Institusi keperawatan hendaknya mengajarkan kepada mahasiswa / I tentang pencegahan penyakit anemia dalam takaran yang lebih mendalam supaya mahasiswa dapat memberikan pendidikan kesehatan kepada para ibu.Institusi pendidikan diharapkan dapat menambah jam belajar aplikasi pembuatan karya ilmiah seperti :Penelitian agar mahasiswa / I lebih mahir dan semakin suka penelitian sehingga lahir generasi ilmiah.

2. Bagi Pelayanan Kesehatan
Pelayanan kesehatan diharapkan dapat memahami pemberian gizi pada balita dan dapat memberikan informasi tentang penyakit - penyakit yang diakibatkan kurangnya nutrisi pada balita dan pencegahannya kepada para ibu di masyarakat.

3. Bagi Ibu yang Memiliki Balita

Ibu yang memiliki balita diharapkan dapat menjaga gizi dan makanan yang akan dikonsumsi balita dan dapat meningkatkan pengetahuan dalam pemberian gizi pada balita. Peneliti Selanjutnya

Peneliti selanjutnya diharapkan untuk dapat melakukan penelitian yang lebih mendalam tentang Gambaran Pengetahua n Ibu TentangPemberian Gizi Pada Balita Diwilayah kerja UPTD Puskesmas Sogae'adu Kabupaten Nias Tahun 2018.

\section{DAFTAR PUSTAKA}

Ashaluddin. (2016).Lembaga penelitian universitas riau. http://www.lemlitur.com/2016/10/lima indikatorpenelitian-menuju.html.

Behavior. (2009). Ilmu Kesehatan Masyaraka t. Jakarta: Rineka Cipta.

Dwijayanti, Linda. (2015). Ilmu Gizi Menjadi Sangat Mudah. Jakarta: EGC.

Mitayani. (2010). Buku Saku Ilmu Gizi. Catatan Pertama. Jakarta: Trans Info Media.

Maulana. (2009). Ilmu Prilaku atau Sikap . Hal203. http: //repository .usu.ac .id/bitstream /2009 / Chapter\%.pdf.

Nikita. (2014). Sehat dan Bugar Berkat Gizi Seimbang Catatan Pertama. Jakarta: Trans Info Media.

Nency, Y. (2015). Gizi Buruk, Ancaman Generasi Yang Hilang. Inpvasi Edisi Vol. 5/XVII/ November 2015: Inovasi Online.

Notoatmojo, S. (2005). Prinsip-Prinsip Dasar Ilmu Kesehatan Masyarakat. Cetakan Ke 2. Jakarta: Rineka Cipta.

Notoatmojo, Soekidjo. (2007). Metodologi Penelitian Kesehatan. Jakarta: Rineka Cipta. 
Notoatmojo, Soekidjo. (2007). Kesehatan Masyarakat. Ilmu dan Seni. Jakarta: Rineka Cipta.

Notoatmojo, Soekidjo. (2010). Promosi Kesehatan dan Ilmu Prilaku. Catatan Pertama. Jakarta: Rineka Cipta.

Nasution, A.H., dkk. (2008). Gizi untuk Kebutuhan Fisiologis Khusus.Terjemaha n. Jakarta: Gramedia.

Proverawati, Atikah; Asfuah, Siti. (2010). Gizi untuk Kebidanan. Yogyakarta: Nuha Medika.

Santosa, Sugeng. (2016). Kesehatan dan Gizi. Jakarta: Rieneka Cipta.
Setiadi. (2007). Metode Penelitian. Jakarta: EGC.

Siswono. (2015). Dua Dari 10 Balita Menderita Gizi Kurang. http://www.med iaindo.co.id.

Suhardjo. (2007). Pemberian Makanan pada Bayi dan Anak. Yogyakarta: Kanisius.

Tarbiah. (2014). Arti Ibu. http://lehor. Student.umm.ac.id/2010/02/06/artiseorang ibu.

Uripin. (2006). Ilmu Konsep Tentang Balita. Jakarta: EGC.

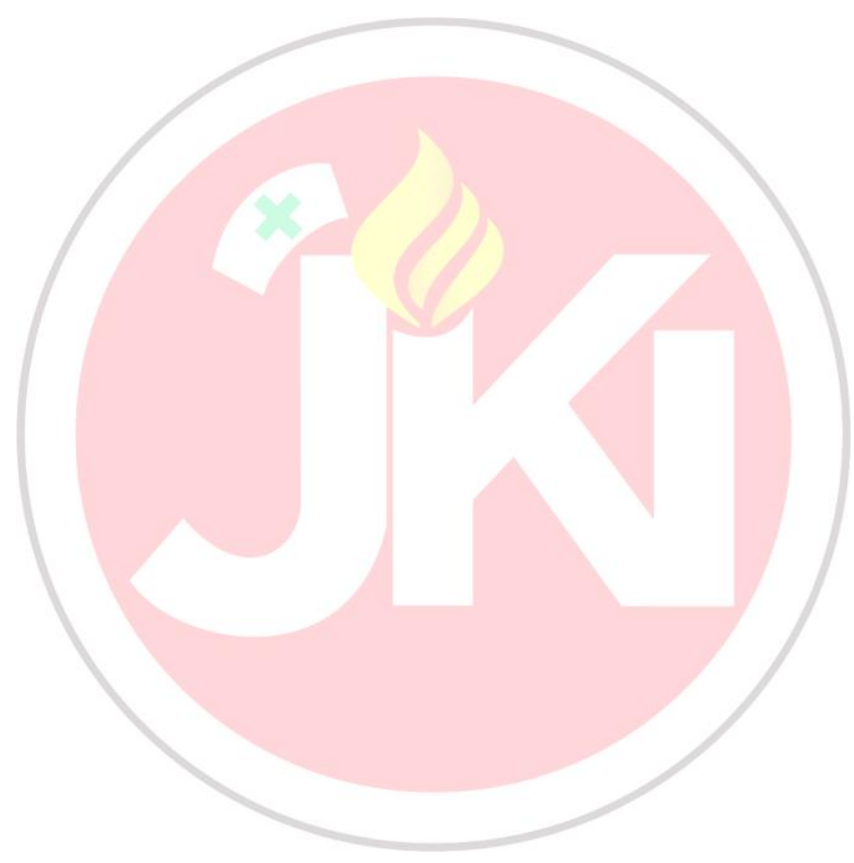

